\title{
Evaluation of Photosynthesis Capacity of Some Winter Wheat Genotypes in Transylvanian Plain Conditions
}

\author{
Ionuț RACZ ${ }^{1 *}$, Rozalia $\mathrm{KADAR}^{1}$, Diana HIRISCĂU ${ }^{1,3}$, Marius BĂRDAŞ ${ }^{1}$, Florin Dumitru BORA ${ }^{2}$, Camelia \\ URDĂ ${ }^{1}$, and Adina TĂRǍU ${ }^{1,3}$ \\ ${ }^{1}$ Agricultural Research and Development Station Turda, Romania. \\ ${ }^{2}$ Department of Physico-Chemistry and Biochemistry. Research Station for Viticulture and Enology Târgu Bujoru, Romania. \\ ${ }^{3}$ University of Agricultural Science and Veterinary Medicine Cluj Napoca, Romania \\ *corresponding author, e-mail: racz_ionut@yahoo.com
}

Bulletin USAMV series Agriculture 75(1)/2018

Print ISSN 1843-5246; Electronic ISSN 1843-5386

DOI 10.15835/buasvmcn-agr: 004617

\begin{abstract}
Leaf photosynthetic capacity is a key parameter determining cropyield; it is enhanced by moderate soil moisture and reduced in both severe water deficit and excessive water conditions. The aim of this work was to evaluate the wheat variety photosynthetic capacity in two main phenological stages. The evaluation of photosynthesis capacity of studied winter wheat varieties in Transylvanian Plain conditions offer relevant information on Romanian genetic material type and paving the way of new research directed to a new wheat breeding program criteria and for improvement of those.
\end{abstract}

Key words: plant phenology, photosynthesis, winter wheat

\section{Introduction}

More than $90 \%$ of crop biomass is derived from photosynthetic products (Makino, 2011). The differences of photosynthesis processes between wheat varieties are determined by capacity and efficiency of those to converse the light energy into plant dry matter. Drought is one of most important environmental factors inhibiting photosynthesis and decreasing growth and productivity of plants. Wheat leaves, especially flag leaf, are important photosynthetic assimilation organs during a jointing stage and anthesis period (Jia et al., 2015). Leaf photosynthetic capacity is a key parameter determining crop yield; it is enhanced by moderate soil moisture and reduced in both severe water deficit and excessive water conditions (Xu and Zhou, 2011). The aim of this work was to evaluate the wheat variety photosynthetic capacity in two main phenological stages.

\section{Materials and Methods}

The biological materials were composed of twelve representative Romanian winter wheat genotypes. Ear emergence (Zadoks 55-59) and kernel development (Zadoks 73-77) were the phenology stages established for measurement, being two main phenophases with high influence on final grain yield. The evaluation of wheat plant photosynthetic capacity were made based on measurement using a CIRAS-3 Portable Photosynthesis System (PP-Systems, Hitchin, UK) on five flag leaves under natural conditions with $390 \mu \mathrm{mol} \mathrm{CO} \mathrm{mol}^{-1}$ air and $24-30^{\circ} \mathrm{C}$ from each experimental plot. All measurements were made 
Table 1. Assimilation rate, transpiration rate, water use efficiency and stomatal conductance in relationship with grain yield during two main winter wheat phenophases

\begin{tabular}{cccccccccc}
\hline \multirow{2}{*}{ Genotype } & $\begin{array}{c}\text { Assimilation } \\
\left(P_{n}\right)\end{array}$ & \multicolumn{2}{c}{$\begin{array}{c}\text { Transpiration rate } \\
\left(T_{r}\right)\end{array}$} & $\begin{array}{c}\text { Water use efficiency } \\
(W U E)\end{array}$ & \multicolumn{2}{c}{$\begin{array}{c}\text { Stomatal } \\
\text { conductance } \\
(g s)\end{array}$} & $\begin{array}{c}\text { Grain yield } \\
\left(\mathrm{t} \mathrm{ha}^{-1}\right)\end{array}$ \\
\cline { 2 - 10 } & Z. 55-59 & Z.73-77 & Z. 55-59 & Z. 73-77 & Z. 55-59 & Z.73-77 & Z. 55-59 & Z.73-77 & \\
\hline V 1 & 26.1 & 20.98 & 2.81 & 2.04 & 9.32 & 10.83 & 176.3 & 342.7 & 5.78 \\
\hline V 2 & 27.93 & 16.72 & 3.21 & 1.5 & 8.7 & 11.19 & 236.3 & 195.7 & 6.33 \\
\hline V 3 & 27.8 & 30.01 & 2.84 & 1.29 & 9.8 & 23.33 & 155.7 & 257.3 & 6.36 \\
\hline V 4 & 28.3 & 26.93 & 5.82 & 0.78 & 4.87 & 37.76 & 412 & 181 & 5.82 \\
\hline V 5 & 35.27 & 23.12 & 3.31 & 1.27 & 10.67 & 23.25 & 260 & 196.7 & 5.94 \\
\hline V 6 & 37.3 & 28.9 & 6.71 & 0.93 & 5.56 & 31.42 & 520.3 & 177 & 5.82 \\
\hline V 7 & 29.93 & 23.17 & 6.03 & 0.77 & 4.96 & 36.44 & 519 & 195.9 & 6.03 \\
\hline V 8 & 38.77 & 14.57 & 6.57 & 1.49 & 5.9 & 9.72 & 423 & 240.6 & 6.34 \\
\hline V 9 & 34.63 & 19.48 & 6.65 & 1.37 & 5.9 & 14.76 & 371 & 254.4 & 6.42 \\
\hline V 10 & 35.97 & 18.36 & 2.95 & 1.39 & 12.18 & 13.08 & 225.7 & 164.1 & 6.73 \\
\hline V 11 & 39.2 & 22.02 & 3.12 & 1.85 & 12.57 & 13.88 & 238 & 267.7 & 5.32 \\
\hline V 12 & 39.2 & 23.63 & 3.13 & 1.49 & 12.51 & 16.96 & 252 & 375.8 & 5.71 \\
\hline Mean & 33.37 & 22.32 & 4.43 & 1.35 & 8.58 & 20.22 & 315.8 & 237.4 & 6.05 \\
\hline CV & 14.98 & 21.10 & 38.83 & 28.89 & 35.31 & 50.05 & 40.47 & 28.16 & 6.48 \\
\hline St. dev. & 5.00 & 4.71 & 1.72 & 0.39 & 3.03 & 10.12 & 127.80 & 66.86 & 0.392 \\
\hline
\end{tabular}

between 9:00 and 11:00 on days with natural full sunlight.

\section{Results and discussions}

The behaviour regarding the photosynthesis parameters of wheat genotypes during the two main phenophases highlights significant differences. The photosynthesis capacity before anthesis stage indicate a high activity (assimilation rate, transpiration rate and stomatal conductance) compared with the post anthesis measurement. The high intensity values of photosynthetic activity before anthesis can be explained by unfinished process of vegetative stages, when the biomass accumulation needs more energy such as transport of nutrients and respiration, meaning about only $10-15 \%$ is allocated to yield. During the ear emergence stage the plant physiological parameter were higher than grain filling period, except WUE which range at kernel development stage. The assimilation values at ear emergence stage were between 26.1 at the first genotype to $39.2 \mu \mathrm{mol} \mathrm{CO} \mathrm{m}^{-2} \mathrm{~s}^{-1}$ by $V_{11}$ and $V_{12}$, while at kernel development stage the variation of this parameter were between 14.57 by $\mathrm{V}_{14}$ and $30.01 \mu \mathrm{mol} \mathrm{CO}_{2}$ $\mathrm{m}^{-2} \mathrm{~s}^{-1}$ at third genotype studied. Transpiration rate mean values range from $1.35 \mathrm{mmol} \mathrm{H}_{2} \mathrm{O} \mathrm{m}^{-2} \mathrm{~s}^{-1}$ at kernel development stage to $4.43 \mathrm{mmol} \mathrm{H}_{2} \mathrm{O} \mathrm{m}^{-2} \mathrm{~s}^{-1}$ at spike emergence which highlights an intensive activity of plant dry matter accumulation on this vegetative stage. WUE is the only parameter whose variation is amplified at the second studied stage, the mean value of those being $20.22 \mathrm{mmol} \mathrm{CO}_{2}$ mol $^{-1} \mathrm{H}_{2} \mathrm{O}$ at kernel development stages compared with $8.58 \mathrm{mmol} \mathrm{CO}_{2} \mathrm{~mol}^{-1} \mathrm{H}_{2} \mathrm{O}$ at head emergence stage.

\section{Conclusion}

Based on the data from this study could have been highlight some performant winter wheat genotypes for physiological proprieties as a breeding material and can be established technical actions intervention to reduce the effect of unfavourable climatic influence. The evaluation of photosynthesis capacity of studied winter wheat varieties in Transylvanian Plain conditions offer relevant information on Romanian genetic material type and paving the way of new research directed to a new wheat breeding program criteria and for improvement of those.

\section{References}

1. Jia S., Lv J., Jiang S., Liang T., Liu C. and Jing Z., 2015, Response of wheat ear photosynthesis and photosynthate carbon distribution to water deficit, Photosynthetica, 53 (1): 95-109.

2. Xu ZZ, Zhou GS, 2011, Responses of photosynthetic capacity to soil moisture gradient in perennial rhizome grass and perennial bunchgrass, BMC Plant Biol 11: 21; doi: 10.1186/1471-2229-11-21.

3. Makino A, 2011, Photosynthesis, Grain Yield, and Nitrogen Utilization in Rice and Wheat, Plant Physiol.; 155(1): 125129. 